УДК 157.931

DOI: http://dx.doi.org/10.30970/vpe.2018.33.9966

\title{
AGGRESSIVENESS OF ADOLESCENTS WITH AUTISM WITH DIFFERENT LEVELS OF SCHOOL ANXIETY
}

\section{Kateryna Ostrovska, Ihor Ostrovskii}

Ivan Franko National University of Lviv, Tuhan-Baranovskoho Str., 7, Lviv, Ukraine, UA-79005

The results of experimental research on aggression factors and levels of anxiety of 20 adolescents with autism in 6-8th forms of secondary schools in Lviv are presented. The following methods were used in the study: Spielberg's questionnaire to determine school anxiety; questionnaire of predisposition to aggression and conflict. The results of the study of school anxiety levels, according to the Spielberg questionnaire, of adolescents with autism showed that $38.4 \%$ of respondents had a high level of anxiety. The results of the survey on the scale of predisposition to aggression and conflict allowed to determine the average indicators of the aggression factors of adolescents with autism, such as inflammation, assertiveness, abusiveness, pertinacity, uncompromisingness, vengeance, suspicion, impatience to the thought of others. On the basis of the statistical analysis data, direct correlation between the factors of aggressiveness and the levels of school anxiety in adolescents with autism has been established. Directions of correction work with adolescents with autism are indicated: to reduce their propensity to aggression, it is necessary to work on reducing the level of anxiety and formation of adequate behavior.

Key words: inclusive education, adolescents with autism, factors of aggression, anxiety.

Introduction. Autism Spectrum Disorders (ASD) diagnosis in children is often accompanied with aggressive behaviour. One in four children with ASD had the aggressive behavior problems [4]. According to Kanne S.M. and Mazurek M.O. [5, 6] the prevalence of aggression in ASD children was even 53\%, with highest prevalence among young children. Taking into account the high level of aggression adolescents with ASDs are more likely to be suspended from school than typically developing peers. Besides, adolescents with ASDs are more physically aggressive at school than typically developing peers [1]. The investigations of [10] have showed that aggressive behavior of typically developing adolescents decreases with age. Older adolescents due to their life experience and intelligence learn to transform physical aggression in other types of aggressive behavior, e.g. verbal aggression, etc. Such a behavior is observed in ASD adolescents: higher IQ/adaptive behavior and older age were associated with more sophisticated types of aggression [2].

(C) Ostrovska K., Ostrovskii I., 2018 
There are contradictory evidences about the aggression demonstrations in boys and girls with ASD. Cristan Farmer et.al believe that among all subjects, sex was not associated with aggression [2]. According to Alison Presmanes Hill et.al sociodemographic factors (age, gender, parent education, race, ethnicity) were unrelated to aggressive behavior problems [1]. Meanwhile, authors of [9] observed substantial gender differences in ASD children. Girls with autism as well as typically functioned children demonstrate disruptive behavior to gain attention or items, or to escape demands in general. For boys with autism, disruptive behavior more often functioned to (a) escape demands that interfere with repetitive behavior, (b) retain access to an item used in repetitive routines, or (c) avoid idiosyncratically aversive sensory stimuli (e.g., ordinary household noises) [9].

Aggression was significantly associated with a number of clinical features, including self-injury, sleep problems, sensory problems, GI problems, communication and social functioning [6]. The presence of aggressive behaviour was significantly associated with increased use of psychotropic drugs and melatonin, lower cognitive functioning, lower ASD severity, and greater comorbid sleep, internalizing, and attention problems [4]. Lower scores on IQ, adaptive behavior, and communication measures were associated with more physical aggression in ASD children [2].

Therapeutic strategies including functional behavioral assessment, reinforcement strategies, and functional communication training may have a significant impact in reducing the frequency and intensity of aggressive behavior in individuals with ASD [3]. According to data of Department of Family and Community Service of Australia, in adolescents with ASDs physical aggression increases as severity of social anxiety increases [1]. On the other hand, high anger control reduces physical aggression in adolescents with ASDs. It is interesting to study the possible correlations between an aggression and school anxiety for ASD adolescents in Ukraine [7,8]. The existing of the correlation allows us to decrease a level of aggressiveness by influence on the anxiety of ASD students.

The present work aims to study possible correlations between an aggression indices and school anxiety of ASD adolescents.

Hypothesis of investigation: there is a direct link between aggression and levels of school anxiety in adolescents with ASD.

\section{Experimental results}

The experimental study of the aggression factors of 20 adolescents with autism spectrum disorders (5 girls and 15 boys) in general schools in Lviv was conducted. The following techniques were used in the study:

1) Spielberg questionnaire for determining school anxiety;

2) A questionnaire of predisposition to aggression and conflict. 
Surveys of the level of school anxiety by the Spielberg questionnaire in adolescents with autism showed that the most frequent is a high level of anxiety (see Fig. 1).

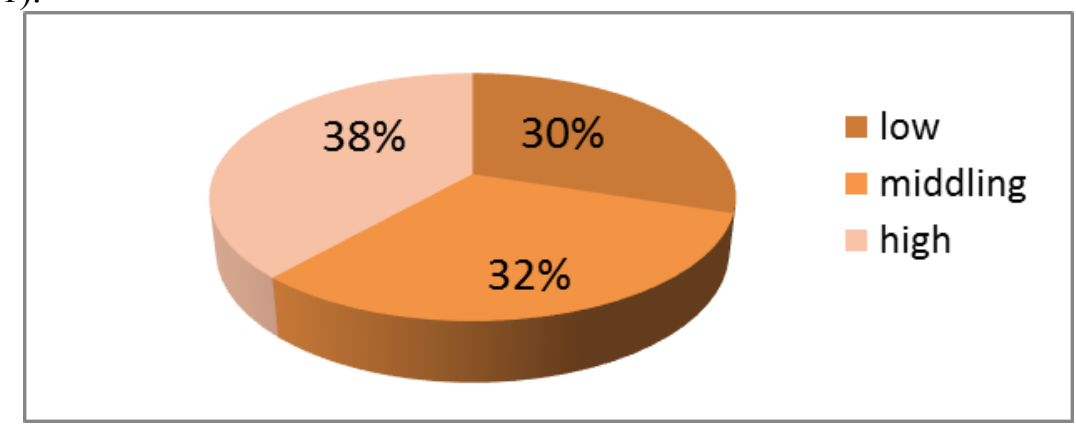

Fig. 1. Indicators of levels of school anxiety in adolescents with autism

According to the results obtained during the study of school anxiety, we found three levels of anxiety in adolescents, among them the rate of $38.4 \%$ shows that in adolescents with autism prevailing high anxiety, a low level of anxiety is observed in $30 \%$ of adolescents and a moderate level of anxiety is inherent in $32 \%$ of the respondents (Fig. 1.).

As a result of a study of aggressive behavior among adolescents with autism, we obtained average scores for inclination to aggression and conflict, which are presented in Table 1.

Table 1. Results on the scale of predisposition to aggression and conflict in adolescents with various level of anxiety

\begin{tabular}{|c|c|c|c|c|c|c|c|c|}
\hline & & & & & & & & \\
\hline $\begin{array}{l}\text { Level of } \\
\text { anxiety }\end{array}$ & 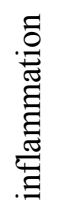 & 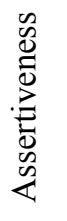 & 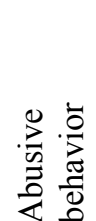 & 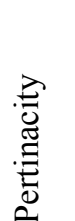 & 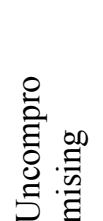 & $\begin{array}{l}\mathscr{\Xi} \\
\bar{\Xi} \\
\Phi_{0} \\
\bar{D} \\
>\end{array}$ & 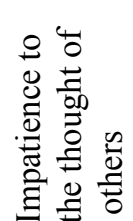 & 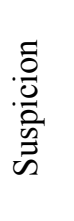 \\
\hline low & 4,2 & 4,7 & 4,6 & 4,3 & 5,3 & 4 & 4,3 & 4,8 \\
\hline moderate & 5,7 & 5,6 & 5,7 & 5,7 & 5,6 & 5,4 & 5,4 & 5,3 \\
\hline high & 5,1 & 5,7 & 5 & 6,3 & 6,5 & 5,3 & 5,5 & 5,7 \\
\hline
\end{tabular}

The values turned out to be average, while the highest figures were found on the "uncompromising" scale. This means that adolescents with autism always try to exercise at their own discretion, do not listen to mentors, teachers, which increases the likelihood of manifestations of deviant behavior in school, can make a mess in conducting lessons. It should be noted that healthy teens also have a tendency to defend their thoughts and ignore compromises and ideas of other people, it is not necessary to expect that the teenager will go on to act, because such an 
uncompromising tendency is observed in this age period. The lowest figure was found on the scale of "vengeance". This means that individuals are not inclined to use aggressive actions in relation to others in the situation of real or predictable injustice.

A comparative analysis of the propensity to aggression and conflict among adolescents with autism (sum in all scales, see Figure 2) showed that the respondents are most often characterized by an average inclination to aggression and conflict (55\%); in the second place the frequency of manifestation is below the level $(26.6 \%)$, the low level is observed in $10 \%$ of the sample, and $8.4 \%$ of the subjects are highly inclined to aggression and conflict.

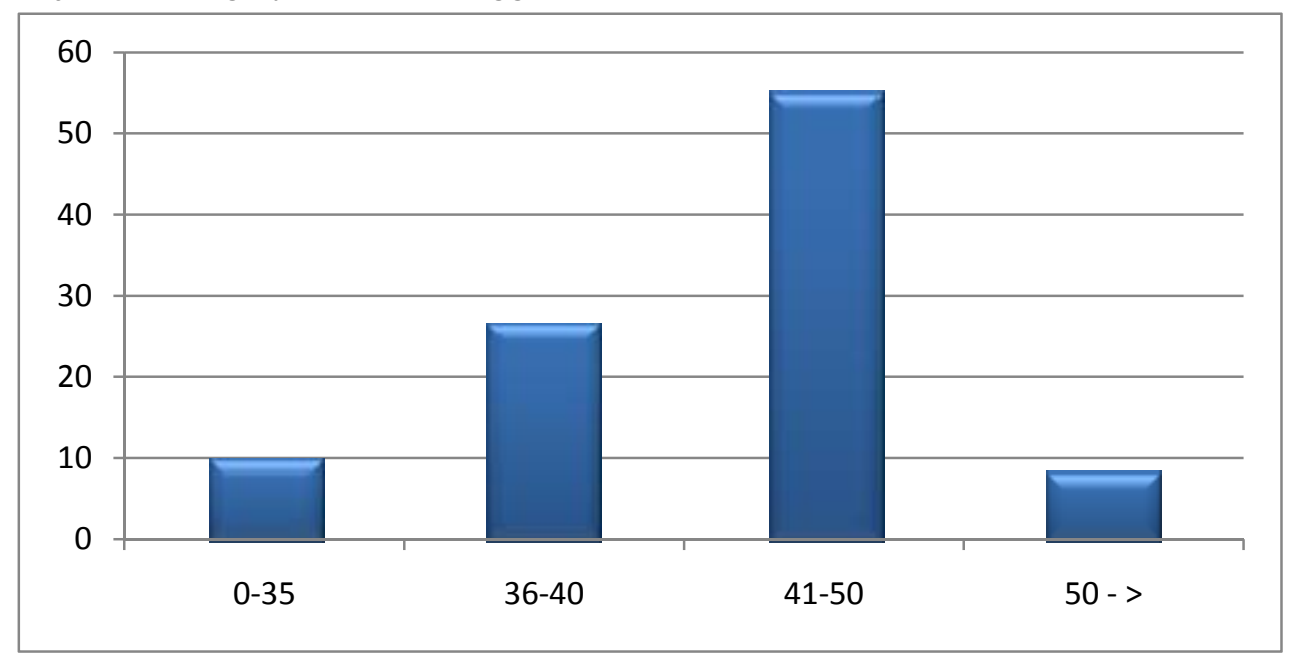

Fig.2. Average indicators of predisposition to aggression and conflict

Since we identified three levels of anxiety in the group under study, mathematical data processing was performed using the Scheffer criterion implemented in the Statistica 8:0 program. By Scheffe's criterion, we tested the relationship of anxiety and predisposition to aggression and conflict in adolescents with autism. The results of the statistical analysis of the dependence of aggression and conflict rates on the level of school anxiety of the study group showed an empirical value of the significance level $p>0.05$, indicating no difference between the investigated features. That is, the aggressiveness of adolescents with autism with different levels of school anxiety is statistically not different.

A comparative analysis of the average indicators of the results of the study of inflammation of adolescents with autism with different levels of school anxiety showed (see Fig. 3) that the highest inclination to inflammation is observed in subjects with moderate anxiety. A slightly lower level of inflection in the subjects with a high level of anxiety, and the lowest result is observed in adolescents with a low level of anxiety. 


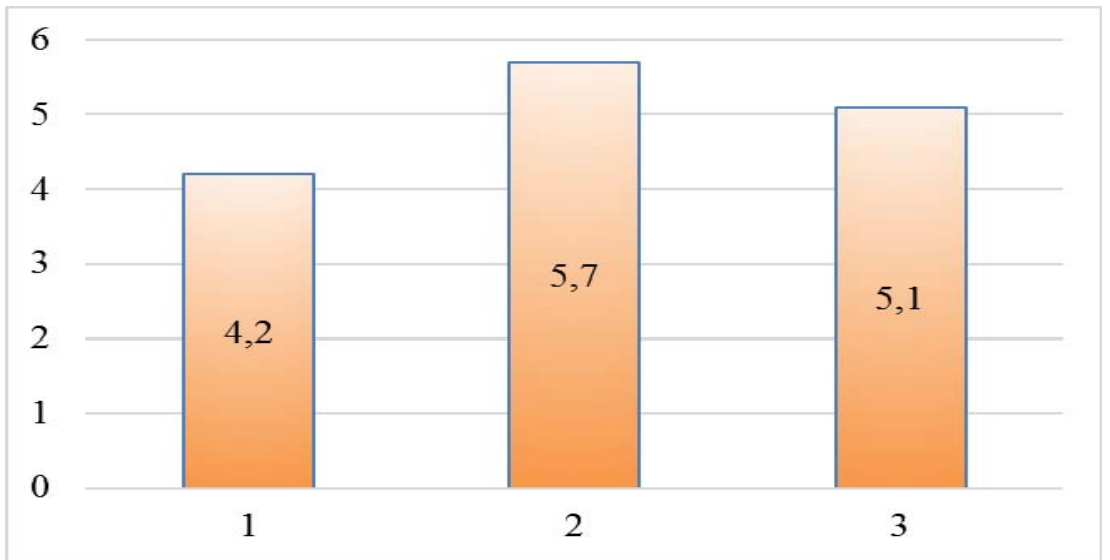

Fig.3. Average indicators of inflammation in adolescents with autism with different levels of school anxiety.

A comparative analysis of the average indices of the study of assertiveness of adolescents with autism with different levels of school anxiety showed (see Figure 4) that the lowest tendency to assertiveness was observed in the individuals with a low level of anxiety. Indicators of assertiveness at moderate and high levels of anxiety are almost identical.

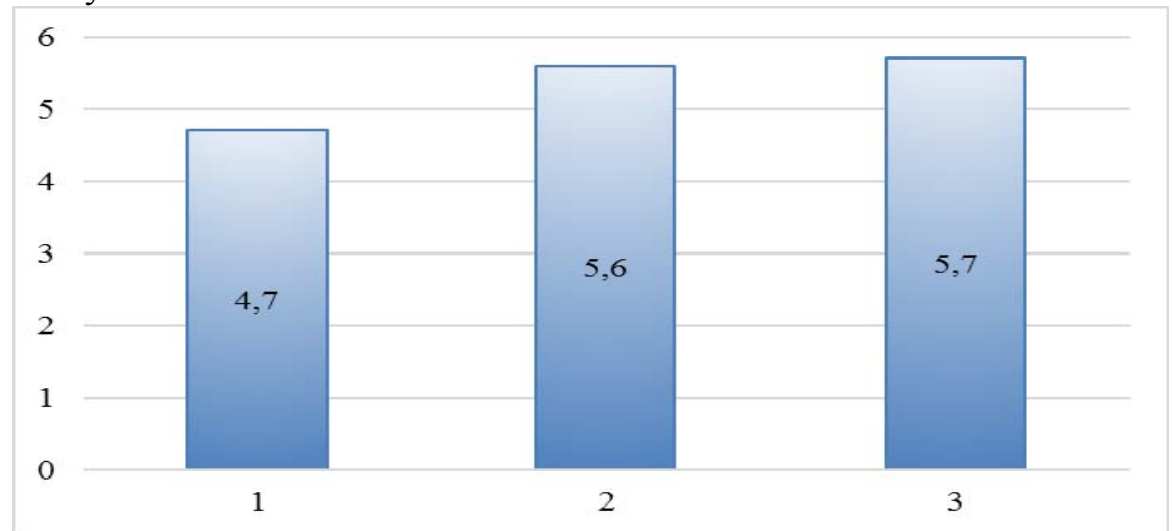

Fig. 4. Average indicators of assertiveness in adolescents with autism with different levels of school anxiety.

A comparative analysis of the average indicators of the results of the survey of abusive behavior among adolescents with autism with varying levels of school anxiety showed (see Figure 5) that the highest inclination to abuse was observed in individuals with moderate anxiety. The lowest indicator of abusive behavior is seen at the lowest level of school anxiety. 


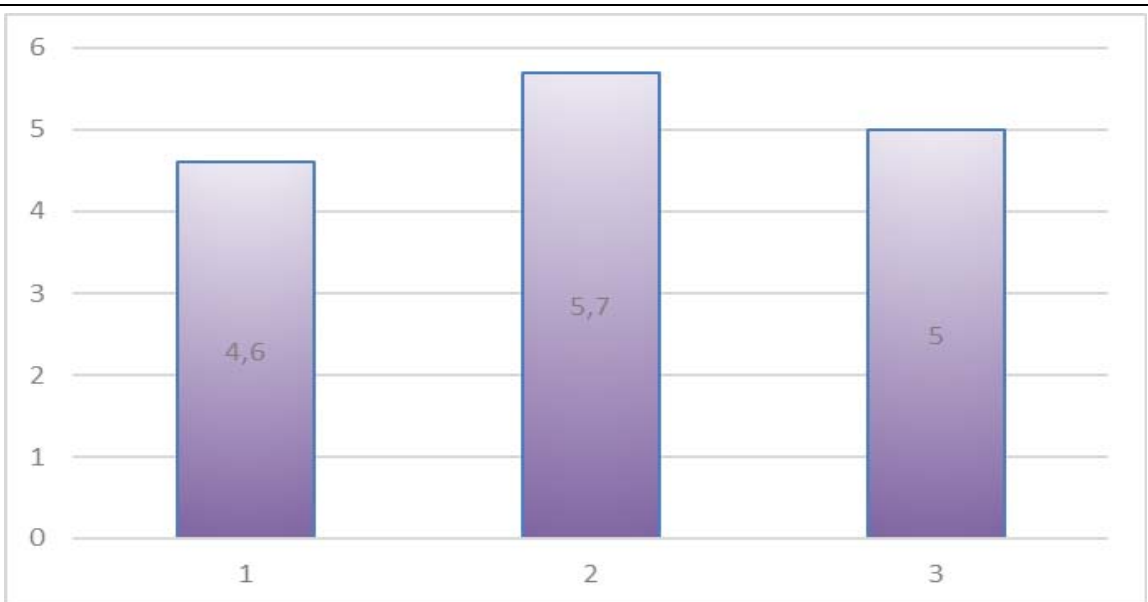

Fig. 5. The average rates of abusive behavior in adolescents with autism with varying levels of school anxiety.

A comparative analysis of the average indices of the study of pertinacity of adolescents with autism with different levels of school anxiety showed (see Figure 6) that the highest tendency to pertinacity is observed in individuals with a high level of anxiety. A slightly lower level of pertinacity in individuals with moderate anxiety, and the smallest indicator of adolescence pertinacity is observed in people with a low level of anxiety.

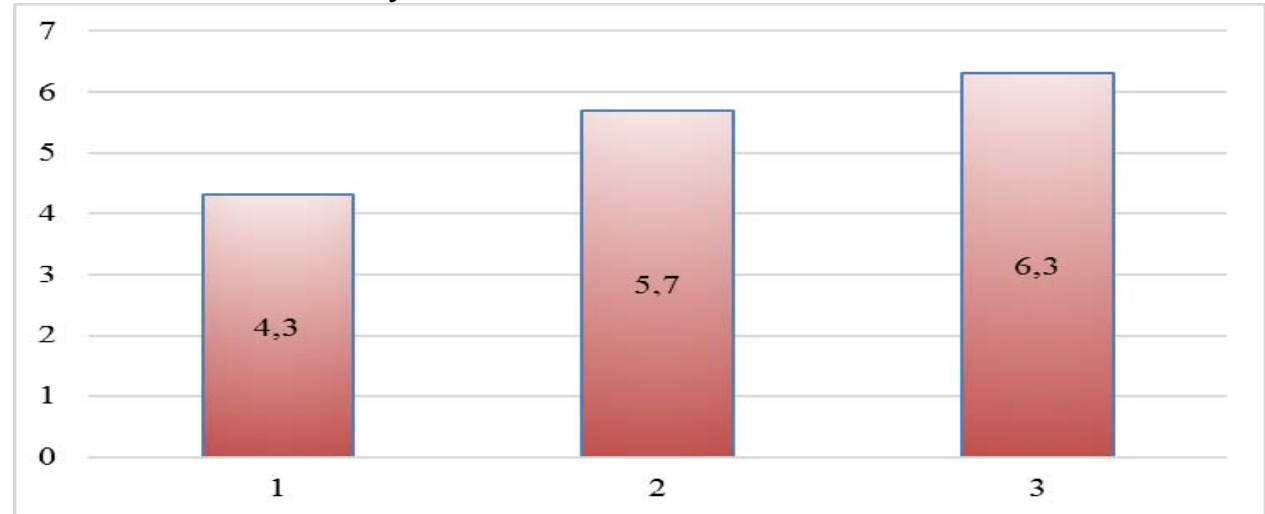

Fig. 6. The average indices of pertinacity of adolescents with autism with varying levels of school anxiety

As we can see from the comparative analysis of the average indicators of the results of the study of uncompromising of adolescents with autism with varying levels of school anxiety (see Fig. 7), the highest uncompromising rate is observed in adolescents with a high level of anxiety. A lower level of uncompromising in the individuals with moderate anxiety and the lowest result is noticeable in people with a low level of anxiety. 


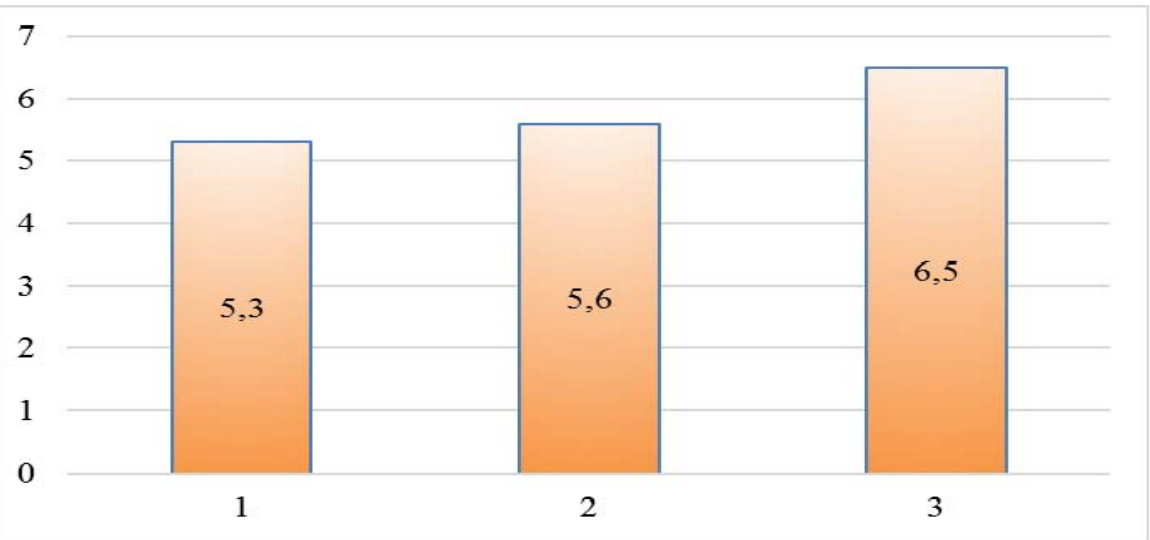

Fig.7. The average indices of uncompromising in adolescents with autism with varying levels of school anxiety.

From the comparative analysis of the average indicators of the results of the study of the vengeance of adolescents with autism with varying levels of school anxiety, we obtain the following data, according to which (see Fig. 2, 8), the indicators of vengeance at a moderate and high level of school anxiety are almost equal, and the lowest inclination to vengeance is characteristic of individuals with a high level of school anxiety.

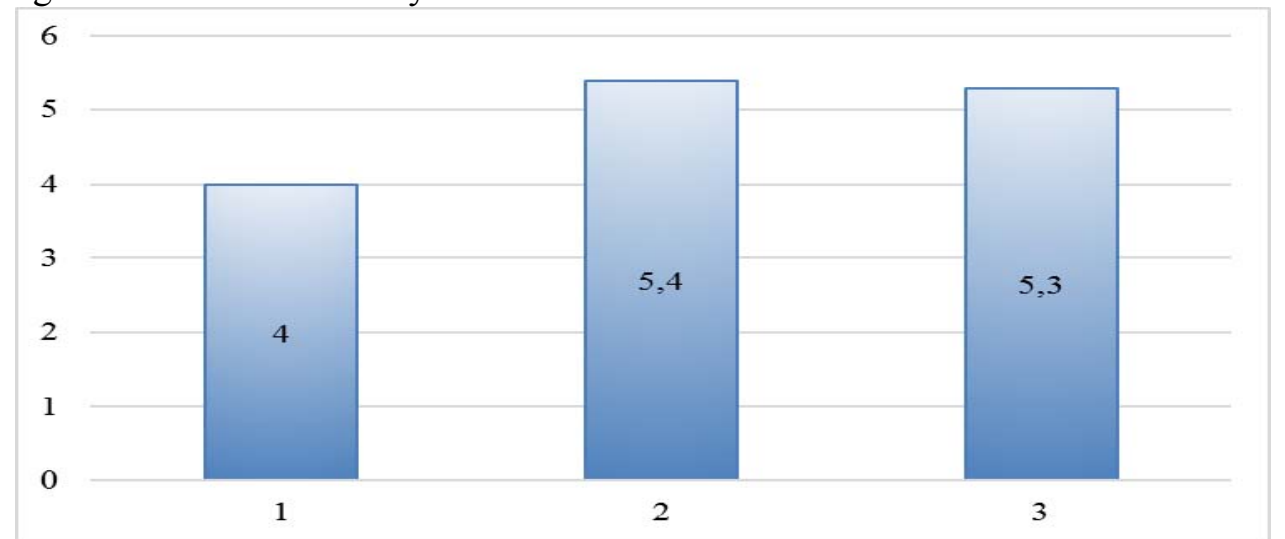

Fig. 8. Average indicators of vengeance in adolescents with autism with varying levels of school anxiety

Comparative analysis of the average indicators of the results of the study of adolescents with autism with different levels of school anxiety in the scale of Impatience to the opinion of others, showed (see Figure 9) that the most often Impatience to the opinion of other people is observed in individuals with a high level of school anxiety and almost the same result at a moderate level of school anxiety. Lower inclination to Impatience to the opinion of others in the subjects with a low level of anxiety. 


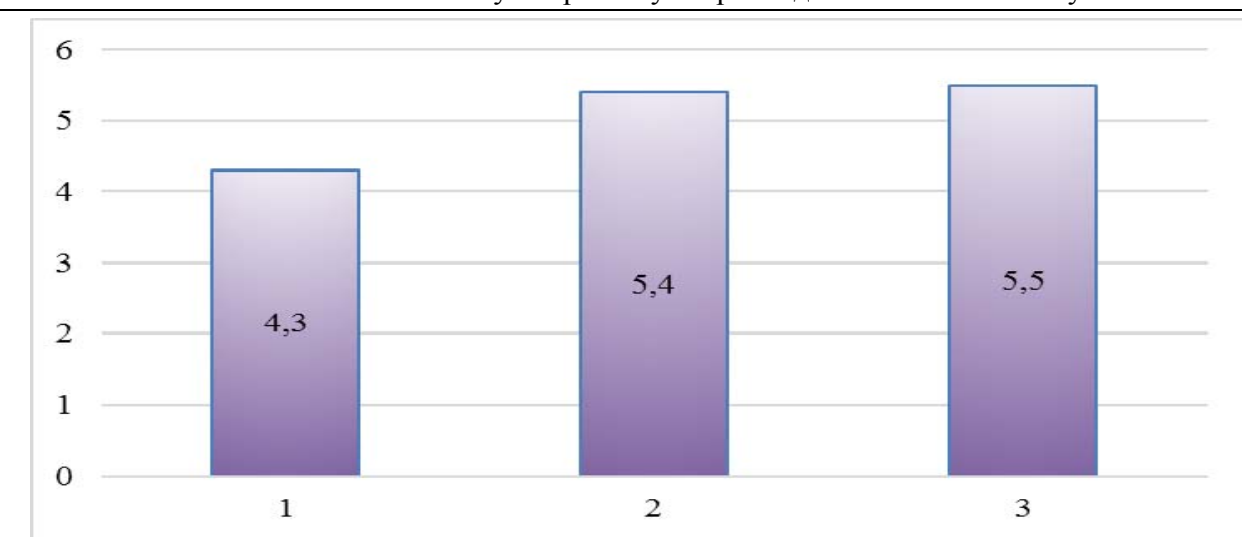

Fig. 9. Average indices of Impatience to the thought of others in adolescents with autism with varying levels of school anxiety

A comparative analysis of the average indicators of the results of the study of suspicion of adolescents with autism with varying levels of school anxiety showed (see Figure 10) that the highest susceptibility is observed in individuals with a high level of anxiety. Lower indicator of suspicion in adolescents with moderate anxiety. The lowest indicator of suspicion is observed in people with a low level of anxiety.

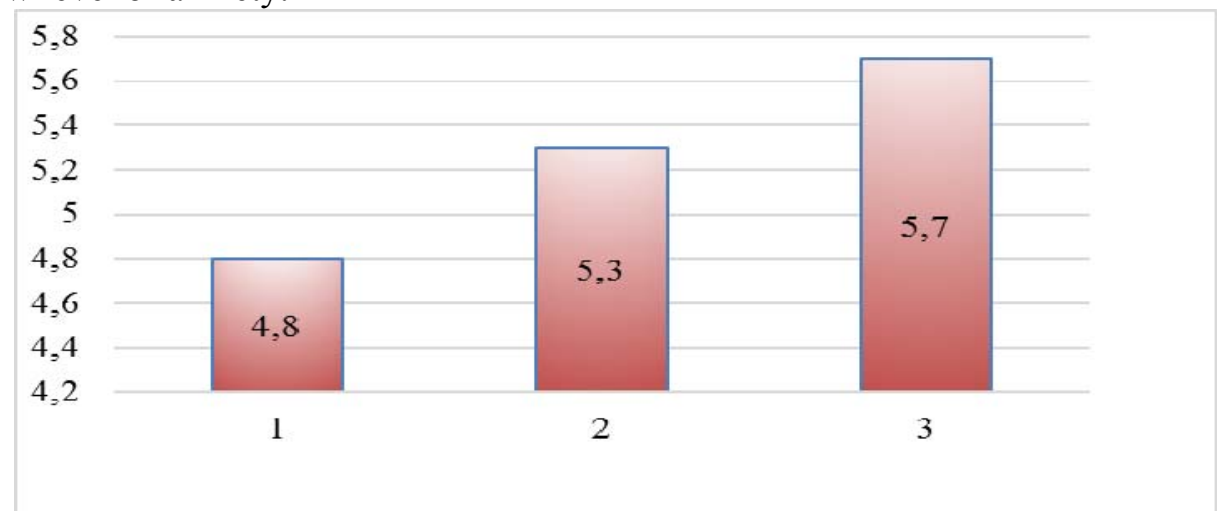

Fig. 10. Average indicators of suspicion of adolescents with autism with varying levels of school anxiety

Consequently, based on a comparative analysis, our hypothesis that there is a direct link between aggression factors and levels of school anxiety in adolescents with autism is statistically denied. However, as a result of the correlation analysis, direct relationships were found between levels of school anxiety and aggression factors of adolescents with autism: inflammation $(p=0.26)$, pertinacity $(p=0.45)$, uncompromising $(p=0.26)$, vengeance $(p=0.34)$, impatience to the thought of others $(p=0.29)$, suspicion $(p=0.31)$. That is, based on correlation analysis data, there is a direct relationship between aggression factors and levels of school 
anxiety in adolescents with autism, which partly confirms the first hypothesis of the study.

The results obtained in the experimental study, namely the identification of direct correlation between the factors of aggression of children with autism and their level of anxiety, allow us to determine the priorities of correctional work. In particular, experiments have shown that adolescents with autism with a high level of anxiety (about $40 \%$ of the sample) are prone to manifestations of aggressiveness in a general school, may exhibit deviant behavior. Consequently, when planning a corrective work of a psychologist at school, it is necessary to work on reducing the level of anxiety for students with autism, that leads to a decrease in the tendency to their aggressive behaviour.

Taking into account the main problematic aspects of inclusive education, practical recommendations for teachers, assistants of teachers, psychologists and social pedagogs are formulated:

- facilitate the establishment of friendly relations between pupils in a natural way;

- teach students to respect their comrades with respect and adhere to the rules of conduct during the interaction;

- make students aware of the need for assistance to be relevant;

- demonstrate positive social behavior to students;

- encourage students to collaborate and exchange services;

- to educate students in tolerance, compassion and understanding of social justice.

\section{Conclusions}

The experimental study of the aggression factors and level of anxiety of 20 adolescents with ASD (5 girls and 15 boys) in general schools in Lviv was conducted. Surveys of level of school anxiety by the Spielberg questionnaire in adolescents with autism showed that $38.4 \%$ of the respondents observed a high level of anxiety. Over $60 \%$ of adolescents have an overestimation of self-esteem. The results of the survey on the scale of predisposition to aggression and conflict allowed to determine the average indicators of the aggression factors of adolescents with autism, such as inflammation, assertiveness, abusiveness, pertinacity, uncompromising, vengeance, suspicion, impatience of the thought of another.

The statistical processing of experimental data was carried out using the application package STATISTICA 8.0, namely, the Sheffer criterion. The results of the statistical analysis of the dependence of aggression and conflict rates on the level of school anxiety of the study group showed an empirical value of the significance level $\mathrm{p}>0.05$, indicating no difference between the investigated features. That is, the aggressiveness of adolescents with autism with different levels of school anxiety is statistically not different. Consequently, based on a comparative analysis, our hypothesis that there is a direct link between aggression 
factors and levels of school anxiety in adolescents with autism is statistically denied. However, as a result of the correlation analysis, direct relationships were found between levels of school anxiety and aggression factors of adolescents with autism: inflammation $(\mathrm{p}=0.26)$, pertinacity $(\mathrm{p}=0.45)$, uncompromising $(\mathrm{p}=$ $0.26)$, vengeance $(p=0.34)$, impartiance to the thought of others $(p=0.29)$, suspicion $(\mathrm{p}=0.31)$. That is, based on correlation analysis data, there is a direct relationship between aggression factors and levels of school anxiety in adolescents with autism, which partly confirms the hypothesis of the study.

The obtained results allow us to plan a corrective work of a psychologist at school. It is necessary to work on reducing the level of anxiety for students with autism, that leads to a decrease in the tendency to their aggressive behaviour.

1. Ambler P.G. Anxiety and aggression in adolescents with autism spectrum disorders attending mainstream schools / Pamela Gaye Ambler, Ami Eidels, Christopher Gregory // Research in Autism Spectrum Disorders. - 2015. - Vol. 18. - P. 97-109.

2. Farmer $C$. Aggression in children with autism spectrum disorders and a clinic-referred comparison group / Cristan Farmer, Eric Butter, Micah O. Mazurek, Charles Cowan, Janet Lainhart, Edwin H. Cook, Mary Beth DeWitt, and Michael Aman // Autism. -2015. - Vol. 19, No.3. - P. 281-291.

3. Fitzpatrick S.E. Aggression in autism spectrum disorder: presentation and treatment options / Sarah E Fitzpatrick, Laura Srivorakiat, Logan K Wink, Ernest V Pedapati, and Craig A Erickson // Neuropsychiatr Dis Treat. - 2016. - Vol. 12. P. $1525-1538$.

4. Hill A. P. Aggressive Behavior Problems in Children with Autism Spectrum Disorders: Prevalence and Correlates in a Large Clinical Sample / Alison Presmanes Hill, Katharine E. Zuckerman, Arlene D. Hagen, Daniel J. Kriz, Susanne W. Duvall, bJan van Santen, Joel Nigg, Damien Fair, and Eric Fombonne // Res Autism Spectr Disord. - 2014. - Vol.8, No. 9. - P. 1121-1133.

5. Kanne S.M. Aggression in children and adolescents with ASD: prevalence and risk factors / S.M. Kanne, M.O. Mazurek // J Autism Dev Disord. - 2011. - Vol.41, No. 7. - P. 926-37.

6. Mazurek M. O. Physical aggression in children and adolescents with autism spectrum disorders / Micah O.Mazurek, Stephen M.Kanne, Ericka L.Wodka // Research in Autism Spectrum Disorders. - 2013. - Vol. 7, Issue 3. - P. 455-465.

7. Ostrovska K. O. Peculiarities of social competence in children with different autistic levels / K. O. Ostrovska // Journal of Education, Culture and Society. - 2012. - No. 1. - P. 133-147. 
8. Ostrovska K.O. Social support of children with ASD during education $/ \mathrm{K}$. O. Ostrovska. - 2009. - Lviv, Triada Plus. -188 p.

9. Reese R. M. Functional characteristics of disruptive behavior in developmentally disabled children with and without autism / R. M. Reese, D. M. Richman, J. M. Belmont, \& P. Morse // Journal of Autism and Developmental Disorders - 2005. - Vol. 35, No. 4. - P. 419-428.

10. Volyanska O.V. Problems of aggressive behavior of adolescents: factors and mechanisms of socialization / O.V. Volyanska // Sociology. - 2016. - No. 3 (30). - P. 117-132 (in Ukrainian).

\section{АГРЕСИВНІСТЬ У ПІДЛІТКІВ 3 АУТИЗМОМ ІЗ РІЗНИМ РІВНЕМ ШКІЛЬНОЇ ТРИВОЖНОСТІ}

\section{Катерина Островська, Ігор Островський}

Львівський національний університет імені Івана Франка, вул. Туган-Барановського, 7, Львів, Украӥна, 79005

Розлади спектру аутизму (РСА) у дітей шкільного віку часто асоціюються 3 агресивною поведінкою. Зокрема, кожен четвертий учень з РСА має прояви агресії. Форми агресивної поведінки у школі видозмінюються з віком учнів - у старшому віці фізична агресія витісняється вербальною. Однак, на сьогодні не має прямих доказів взаємозв'язку агресивної поведінки з шкільною тривожністю дітей з РСА.

У роботі наведені результати експериментального дослідження чинників агресії та рівня тривожності 20 підлітків 3 аутизмом 6-8-х класів загальноосвітніх шкіл м. Львова. У дослідженні було застосовано наступні методики: опитувальник Спілберга для визначення шкільної тривожності; опитувальник схильності до агресії та конфліктності. Результати дослідження рівня шкільної тривожності за опитувальником Спілберга у підлітків з аутизмом показали, що у $38,4 \%$ опитуваних спостерігається високий рівень тривожності. Результати опитування за шкалами схильності до агресивності та конфліктності дозволили визначити середні показники чинників агресивності підлітків 3 аутизмом, таких як запальність, напористість, образливість, непоступливість, безкомпромісність, мстивість, підозріливість, 
Kateryna Ostrovska, Ihor Ostrovskii

ISSN 2078-5526. Вісник Львівського університету. Серія педагогічна. 2018. Випуск 33

неприйняття думки іншого. Отримані результати аналізувались за допомогою статистичного пакету Statistica 8:0. На основі даних порівняльного аналізу 3 використанням критерію Шеффе досліджувався взаємозв'язок між шкалою шкільної тривожності підлітків 3 аутизмом та шкалами їх схильності до агресивності та конфліктності. Значимих зв'язків в межах р>0.05 між даними шкалами виявлено не було. На основі проведеного кореляційного аналізу встановлено прямі кореляційні зв'язки між чинниками агресивності та рівнями шкільної тривожності у підлітків 3 аутизмом, що частково підтверджує гіпотезу дослідження. Виходячи з цього вказано напрямки корекційної роботи з підлітками з аутизмом: для зниження їх схильності до агресії необхідно працювати над зниженням рівня тривожності та формуванням адекватної поведінки.

Ключові слова: інклюзивна освіта, підлітки 3 аутизмом, чинники агресії, тривожність 